\title{
Amyloid-Beta Modulates Low-Threshold Activated Voltage- Gated L-Type Calcium Channels of Arcuate Neuropeptide Y Neurons Leading to Calcium Dysregulation and Hypothalamic Dysfunction
}

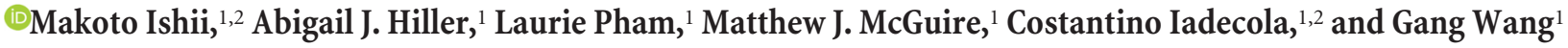 \\ ${ }^{1}$ Feil Family Brain and Mind Research Institute, Weill Cornell Medicine, New York, New York 10065, and ${ }^{2}$ Department of Neurology, Weill Cornell \\ Medicine, New York, New York 10065
}

Weight loss is an early manifestation of Alzheimer's disease that can precede the cognitive decline, raising the possibility that amyloid- $\beta$ $(\mathrm{A} \beta$ ) disrupts hypothalamic neurons critical for the regulation of body weight. We previously reported that, in young transgenic mice overexpressing mutated amyloid precursor protein ( $\mathrm{Tg} 2576$ ), $\mathrm{A} \beta$ causes dysfunction in neuropeptide $\mathrm{Y}$ (NPY)-expressing hypothalamic arcuate neurons before plaque formation. In this study, we examined whether A $\beta$ causes arcuate NPY neuronal dysfunction by disrupting intracellular $\mathrm{Ca}^{2+}$ homeostasis. Here, we found that the L-type $\mathrm{Ca}^{2+}$ channel blocker nimodipine could hyperpolarize the membrane potential, decrease the spontaneous activity, and reduce the intracellular $\mathrm{Ca}^{2+}$ levels in arcuate NPY neurons from Tg2576 brain slices. In these neurons, there was a shift from high to low voltage-threshold activated L-type $\mathrm{Ca}^{2+}$ currents, resulting in increased $\mathrm{Ca}^{2+}$ influx closer to the resting membrane potential, an effect recapitulated by A $\beta_{1-42}$ and reversed by nimodipine. These low voltage-threshold activated L-type $\mathrm{Ca}^{2+}$ currents were dependent in part on calcium/calmodulin-dependent protein kinase II and IP ${ }_{3}$ pathways. Furthermore, the effects on intracellular $\mathrm{Ca}^{2+}$ signaling by both a positive (ghrelin) and negative (leptin) modulator were blunted in these neurons. Nimodipine pretreatment restored the response to ghrelin-mediated feeding in young (3-5 months), but not older ( 10 months), female Tg2576 mice, suggesting that intracellular $\mathrm{Ca}^{2+}$ dysregulation is only reversible early in $\mathrm{A} \beta$ pathology. Collectively, these findings provide evidence for a key role for low-threshold activated voltage gated $\mathrm{L}$-type $\mathrm{Ca}^{2+}$ channels in $\mathrm{A} \beta$-mediated neuronal dysfunction and in the regulation of body weight.

Key words: Alzheimer's disease; electrophysiology; ghrelin; hypothalamus; leptin; neuropeptide Y

Significance Statement

Weight loss is one of the earliest manifestations of Alzheimer's disease (AD), but the underlying cellular mechanisms remain unknown. Disruption of intracellular $\mathrm{Ca}^{2+}$ homeostasis by amyloid- $\beta$ is hypothesized to be critical for the early neuronal dysfunction driving $\mathrm{AD}$ pathogenesis. Here, we demonstrate that amyloid- $\beta$ causes a shift from high to low voltage-threshold activated $\mathrm{L}$-type $\mathrm{Ca}^{2+}$ currents in arcuate neuropeptide $\mathrm{Y}$ neurons. This leads to increased $\mathrm{Ca}^{2+}$ influx closer to the resting membrane potential, resulting in intracellular $\mathrm{Ca}^{2+}$ dyshomeostasis and neuronal dysfunction, an effect reversible by the $\mathrm{L}$-type $\mathrm{Ca}^{2+}$ channel blocker nimodipine early in amyloid- $\beta$ pathology. These findings highlight a novel mechanism of amyloid- $\beta$-mediated neuronal dysfunction through L-type $\mathrm{Ca}^{2+}$ channels and the importance of these channels in the regulation of body weight.

\section{Introduction}

Weight loss is a common manifestation of Alzheimer's disease (AD) and since the 1984 consensus statement has been a criterion

Received March 13, 2019; revised July 17, 2019; accepted Sept. 11, 2019

Author contributions: M.I., C.I, and G.W. designed research; M.I., A.J.H., L.P., M.J.M., and G.W. performed research; M.I., A.J.H., and G.W. analyzed data; M.I. wrote the first draft of the paper; M.I., A.J.H., L.P., M.J.M., C.I., and G.W. edited the paper; M.I. and G.W. wrote the paper.

This work was supported by the National Institutes of Health Grant NS37853 to C.I. and Grant AG051179 to M.I. The support of Lauren and Andy Weisenfeld is gratefully acknowledged. We thank Dr. Anjali Rajadhyaksha for consistent with the diagnosis of AD (McKhann et al., 1984). In epidemiological studies, early weight loss in $\mathrm{AD}$ was associated

helpful discussions; Daniel Lee for technical support; and Alicia Savage-Nieves, Sophy Aguilar, Heather Blades, and Karen Carter for administrative support.

The authors declare no competing financial interests.

Correspondence should be addressed to Makoto Ishii at mishii@med.cornell.edu.

M.J. McGuire's present address: Department of Neurosurgery, Jacobs School of Medicine and Biomedical Science, Buffalo, NY 14203.

https://doi.org/10.1523/JNEUROSCI.0617-19.2019

Copyright $\odot 2019$ the authors 
with worsening disease progression and increased mortality, whereas weight gain was protective (White et al., 1998), suggesting that the factors involved in maintaining body weight are likely to be intrinsic to $\mathrm{AD}$ pathogenesis. Importantly, weight loss can precede the cognitive decline in $\mathrm{AD}$, suggesting that systemic metabolic dysfunction occurs during the preclinical stage of $\mathrm{AD}$, where neuropathological abnormalities, such as hyperphosphorylated tau and amyloid- $\beta(\mathrm{A} \beta)$, have started to accumulate but have not caused significant cognitive impairment (Johnson et al., 2006; Gao et al., 2011; Emmerzaal et al., 2015). Despite the evidence supporting the importance of early systemic metabolic dysfunction in $\mathrm{AD}$, the underlying mechanisms have not been elucidated but could conceivably be due to disruption of brain circuits regulating body weight (Ishii and Iadecola, 2015).

Neurons that coexpress neuropeptide Y (NPY) and agoutirelated peptide in the arcuate nucleus of the hypothalamus are major orexigenic or positive regulators of body weight (Loh et al., 2015). Leptin is an adipocyte-derived hormone that maintains body weight homeostasis by acting as the negative afferent signal to the brain, where it can inhibit arcuate NPY neurons (McGuire and Ishii, 2016). Conversely, ghrelin is a stomach-derived peptide that can increase feeding and alter systemic metabolism by stimulating arcuate NPY neurons (Yanagi et al., 2018). Therefore, leptin and ghrelin regulate body weight in large part by modulating arcuate NPY neuronal function. We previously found that a transgenic mouse model of $A \beta$ accumulation (Tg2576 mice), at a young age ( 3 months) before developing amyloid plaques, exhibited early body weight deficits and low plasma leptin levels that were due to increased energy expenditure and not from changes in feeding behavior (Ishii et al., 2014). Furthermore, the systemic metabolic deficits in this mouse model were associated with depolarized membrane potentials in arcuate NPY neurons and a blunted response to both leptin and ghrelin (Ishii et al., 2014). Collectively, these results are consistent with $\mathrm{A} \beta$ causing arcuate NPY neuronal dysfunction, leading to early systemic metabolic deficits; however, how $\mathrm{A} \beta$ causes dysfunction in these neurons is not known.

Since intracellular $\mathrm{Ca}^{2+}$ signaling mechanisms play a key role in the regulation of arcuate NPY neurons by leptin and ghrelin (Kohno et al., 2003; Wang et al., 2008), intracellular $\mathrm{Ca}^{2+}$ dyshomeostasis may underlie the $\mathrm{A} \beta$-mediated dysfunction of these neurons. Decades of accumulating evidence have led to the hypothesis that early disruption of intracellular $\mathrm{Ca}^{2+}$ signaling is critical for the neuronal dysfunction and driving $\mathrm{AD}$ pathogenesis (Alzheimer's Association Calcium Hypothesis Workgroup, 2017). This disruption of intracellular $\mathrm{Ca}^{2+}$ homeostasis by $\mathrm{A} \beta$ is thought to begin at the plasma membrane (Goodison et al., 2012). Therefore, in this study, we tested the hypothesis that $A \beta$ pathology can cause arcuate NPY neuronal dysfunction by disrupting intracellular $\mathrm{Ca}^{2+}$ homeostasis through the modulation of voltage-gated $\mathrm{Ca}^{2+}$ channels. Using brain slices or dissociated neurons from young Tg2576 mice, we found that arcuate NPY neurons have aberrant hyperactivity and increased intracellular $\mathrm{Ca}^{2+}$ levels, an effect recapitulated in WT arcuate NPY neurons treated with exogenous $\mathrm{A} \beta_{1-42}$ and reversed by the dihydropyridine L-type $\mathrm{Ca}^{2+}$ channel blocker nimodipine. Whole-cell recordings demonstrated that these arcuate NPY neurons switched from high to low voltage-threshold activated L-type $\mathrm{Ca}^{2+}$ currents, resulting in increased $\mathrm{Ca}^{2+}$ influx and neuronal dysfunction. Furthermore, nimodipine rescued ghrelin-mediated feeding in young (3-5 months), but not older (10 months), $\mathrm{Tg} 2576$ mice, suggesting that $\mathrm{A} \beta$-mediated $\mathrm{Ca}^{2+}$ neurotoxicity is reversible only during the early stages of $\mathrm{A} \beta$ pathology. These findings show that $\mathrm{A} \beta$ disrupts intracellular $\mathrm{Ca}^{2+}$ homeostasis and neuronal function through low voltage-threshold activated L-type $\mathrm{Ca}^{2+}$ currents and that L-type $\mathrm{Ca}^{2+}$ channels in arcuate NPY neurons play an important role in the regulation of body weight.

\section{Materials and Methods}

Animals. All procedures were approved by the Institutional Animal Care and Use Committee of Weill Cornell Medicine. Experiments were performed in the Tg2576 transgenic line, which overexpresses the Swedish mutant (K670N, M671L) human amyloid precursor protein gene $\left(A P P_{\text {swe }}\right)$ driven by the hamster prion protein promoter (RRID:MGI:3710766) (Hsiao et al., 1996). For NPY-GFP mice, we used the previously wellcharacterized BAC transgenic NPY-hrGFP mouse line (B6.FVBTg(NPY-hrGFP)1Lowl/J, The Jackson Laboratory, catalog \#006417, RRID:IMSR_JAX:006417) (van den Pol et al., 2009; Ishii et al., 2014). To generate Tg2576 mice with GFP labeling in NPY neurons, we crossed male Tg2576 mice with female NPY-GFP mice to produce hemizygous NPY-GFP mice with or without a copy of the $A P P_{\text {swe }}$ transgene. WT littermates lacking the $A P P_{\text {swe }}$ transgene were used as controls. All mice were derived from an in-house colony and housed in climate-controlled $12 \mathrm{~h}$ light-dark cycle rooms with free access to water and standard rodent chow (LabDiet, catalog \#5053).

Preparation of hypothalamic slices and whole-cell patch-clamp studies. Three- to 4-month-old young male and female NPY-GFP hemizygous mice with or without a copy of the $A P P_{\text {swe }}$ transgene were used in all electrophysiology experiments. The mice were anesthetized with $2 \%$ isoflurane, and their brains were rapidly removed and immersed into icecold sucrose (s)-ACSF composed of the following (in mM): 248 sucrose, $26 \mathrm{NaHCO}_{3}, 1 \mathrm{NaH}_{2} \mathrm{PO}_{4}, 5 \mathrm{KCl}, 5 \mathrm{MgSO}_{4}, 0.5 \mathrm{CaCl}_{2}$, and 10 glucose, gassed with $95 \% \mathrm{O}_{2} / 5 \% \mathrm{CO}_{2}, \mathrm{pH} 7.3$. Coronal slices (200 $\mu$ m thick) containing the hypothalamic arcuate nuclei were obtained using a VT1000s Vibratome (Leica Microsystems) and stored in a self-designed chamber containing lactic acid (l)-ACSF composed of the following (in mM): $124 \mathrm{NaCl}, 26 \mathrm{NaHCO}_{3}, 5 \mathrm{KCl}, 1 \mathrm{NaH}_{2} \mathrm{PO}_{4}, 2 \mathrm{MgSO}_{4}, 2 \mathrm{CaCl}_{2}, 10$ glucose, and 4.5 lactic acid, gassed with $95 \% \mathrm{O}_{2} / 5 \% \mathrm{CO}_{2}$ and $\mathrm{pH} 7.4$, at $32^{\circ} \mathrm{C}$ for $1 \mathrm{~h}$, and then the hypothalamic slice was transferred to a glassbottom recording chamber (P-27; Warner Instrument) mounted on an E600 epifluorescence microscope (Nikon) stage. The slices were continuously perfused with the oxygenated l-ACSF at $2 \mathrm{ml} / \mathrm{min}$. Under the microscope equipped with $40 \times$ water-immersion lens and the FITC filter (Chroma Technology), the arcuate nuclei were identified in the ventromedial portion near the base of the third ventricle with GFP-labeled NPY neurons in slices consistently displaying intense green fluorescence and the visualized whole-cell recordings were conducted only on GFPlabeled neurons (Ishii et al., 2014). The patch glass electrode was pulled using borosilicate capillaries (OD $1.5 \mathrm{~mm} / \mathrm{ID} 0.86 \mathrm{~mm}$; World Precision Instruments) and P-80 micropipette puller (Sutter Instruments).

Current-clamp mode was used to record the membrane potential and spontaneous discharges in arcuate NPY neurons in slices. The resistance of the pipette was 5-7 $\mathrm{m} \Omega$ when filled with an intracellular solution containing the following (in $\mathrm{mm}$ ): $130 \mathrm{~K}$-gluconate, $10 \mathrm{NaCl}, 1.6 \mathrm{MgCl}_{2}, 0.1$ EGTA, 10 HEPES, and $2 \mathrm{Mg}$-ATP, adjusted to $\mathrm{pH}$ 7.3. The GFP-positive arcuate neurons were current-clamped using an Axopatch 200A amplifier (filtered at $2 \mathrm{kHz}$, digitized at $10 \mathrm{kHz}$ ) and Digidata 1320A (Molecular Devices). After a Giga $\Omega$ seal formation, brief negative pressure was further applied to obtain the whole-cell configuration. The recording began with the membrane test for monitoring the access resistance, which was continuously monitored through the recording. Only those cells in which access resistance was stable (change $<10 \%$ ) were included in data analysis. The voltage and current signals were filtered at $2 \mathrm{kHz}$, digitalized online at a sampling rate of $10 \mathrm{kHz}$, and stored for offline analysis using pClamp 10 software (Molecular Devices). Stable baseline recordings were achieved before local application of vehicle (PBS), ghrelin $(100 \mathrm{nM}), \omega$-Cgtx-GVIA $(1 \mu \mathrm{M}), \omega$-AgaIVA $(1 \mu \mathrm{M})$, oligomeric $\mathrm{A} \beta_{1-42}(100 \mathrm{nM})$ or nimodipine $(2 \mu \mathrm{M})$ to the bath. The concentration of ghrelin was based on previously published studies showing good physiological responses in arcuate NPY neurons (Cowley et al., 2003). 
Voltage-clamp mode was used to record L-type voltage-gated $\mathrm{Ca}^{2+}$ currents in arcuate NPY neurons in slices. The resistance of the pipette was $3-5 \mathrm{M} \Omega$ when filled with an intracellular solution containing the following (in $\mathrm{mM}$ ): 100 CsCl, 30 TEA-Cl, $1 \mathrm{MgCl}_{2}, 10$ EGTA, $4 \mathrm{NaCl}$, 10 HEPES, $3 \mathrm{Na}_{2}$-ATP, adjusted to $\mathrm{pH}$ 7.3. Voltage-gated $\mathrm{Ca}^{2+}$ currents were recorded from GFP-labeled arcuate NPY neurons using an Axopatch 200A amplifier (filtered at $2 \mathrm{kHz}$, digitized at $10 \mathrm{kHz}$ ), Digidata 1320A (Molecular Devices), and pClamp 10 software (Molecular Devices). Following a Giga $\Omega$ seal formation with a further brief negative pressure applied to obtain the whole-cell configuration. Using $5 \mathrm{mM} \mathrm{Ba}^{2+}$ as the charge carrier, the voltage-gated $\mathrm{Ca}^{2+}$ channel currents were elicited from the holding potential of $-60 \mathrm{mV}$ to stepping potentials ranging from -50 to 20 $\mathrm{mV}$. The recording began with the membrane test for monitoring the access resistance, which was continuously monitored throughout the recording. Stable baseline recordings were achieved before local application of vehicle (PBS), leptin (100 nM, Sigma-Aldrich), or oligomeric $A \beta_{1-42}(100 \mathrm{~nm})$ to the bath. The concentrations of leptin and oligomeric $A \beta_{1-42}$ were chosen based on previously published studies showing good physiological responses in arcuate NPY neurons (Berman et al., 2008; Baver et al., 2014; Ishii et al., 2014). Only those cells in which access resistance was stable (change $<5 \%$ ) were included for data analysis. The $\mathrm{Ca}^{2+}$ channel current amplitudes were expressed as mean \pm SEM, with $N$ as the number of neurons tested from a minimum of 3 mice per group. The L-type $\mathrm{Ca}^{2+}$ current was measured as the amplitude of $\mathrm{Ca}^{2+}$ currents at the end of the $500 \mathrm{~ms}$ depolarizing pulse, whereas the amplitude of the transient fast inactivating $\mathrm{Ca}^{2+}$ current was obtained by subtracting the amplitude of the L-type $\mathrm{Ca}^{2+}$ current from the peak transient $\mathrm{Ca}^{2+}$ currents measured at 30 $\mathrm{ms}$ after initiation of depolarization pulse. The current-voltage relationship $(I-V)$ curves were plotted for each recording. The cell area was determined using the cell membrane capacitance $(\mathrm{pF})$, and the density of the $\mathrm{Ca}^{2+}$ channel currents ( $\mathrm{pA})$ was expressed as $\mathrm{pA} / \mathrm{pF}$.

Assessment of cytoplasmic $\mathrm{Ca}^{2+}$ levels in arcuate NPY-GFP neurons. Three- to 4-month-old young male or female NPY-GFP hemizygous mice with or without a copy of the $A P P_{\text {swe }}$ transgene were used. Cytoplasmic-free $\mathrm{Ca}^{2+}$ was measured using fura-2 $\mathrm{AM}$ as the indicator (Invitrogen), as previously described (Koizumi et al., 2018). The isolated arcuate NPY-GFP neurons were obtained using enzymatic digestion with $0.05 \%$ thermolysin plus $0.05 \%$ pronase (Sigma-Aldrich). Fura-2 AM (25 $\mu \mathrm{M}$ ) was loaded to the cells for $45 \mathrm{~min}$ at $37^{\circ} \mathrm{C}$ and then transferred to polyornithine-coated glass-bottom Petri dish (Warner Instruments). Images were acquired on a Nikon 300 inverted microscope by using a fluorite oil-immersion lens (Nikon CF UV-F X40; NA, 1.3). Fura-2 AM was alternately excited through narrow bandpass filters ( 340 and 380 $\mathrm{nm}$ ). An intensified CCD camera (Retiga, ExI) recorded the fluorescence emitted by the indicator $(510 \pm 40 \mathrm{~nm})$. Fluorescent images were digitized, and backgrounds were subtracted. GFP-labeled cells were simultaneously recorded in a randomly selected field. Fluorescence measurements were obtained from cell body, and ratios were calculated for each pixel by using a standard formula. Results were expressed as 340/380 $\mathrm{nm}$ ratio. Leptin (100 nM), ghrelin (100 nM), $\mathrm{A} \beta_{1-42}(100 \mathrm{~nm})$, and nimodipine $(2 \mu \mathrm{M})$ were perfused for $20 \mathrm{~min}$, respectively.
Preparation of oligomeric $A \beta_{1-42}$. Soluble oligomeric $A \beta_{1-42}$ was freshly prepared from lyophilized solid human synthetic $\mathrm{A} \beta_{1-42}$ (rPeptide, catalog \#A-1002) as previously described (Ishii et al., 2014). Briefly, lyophilized $\mathrm{A} \beta_{1-42}$ was suspended in 1,1,1, 3,3,3 hexafluoro-2-propanol (Sigma-Aldrich) to $1 \mathrm{~mm}$ using a gas-tight syringe. The peptide solution was aliquoted and lyophilized using a Speed-Vac. Dried peptide was stored at $-80^{\circ} \mathrm{C}$ until additional processing. Immediately before the electrophysiology or calcium imaging experiments, dried peptide was resuspended in anhydrous DMSO (Sigma-Aldrich), bath-sonicated for 10 min, and diluted to $100 \mathrm{~mm}$ in PBS. The $\mathrm{A} \beta_{1-42}$ was then allowed to oligomerize by incubation at $4^{\circ} \mathrm{C}$ for $24 \mathrm{~h}$. After incubation, the peptide solution was centrifuged to remove insoluble aggregates. The supernatant containing the soluble oligomeric $\mathrm{A} \beta_{1-42}$ was removed and used for the electrophysiology and calcium imaging experiments as described.

Ghrelin-induced feeding experiments. A randomized controlled crossover design was used for the feeding experiments. Three- to 5-month-old female Tg2576 or WT littermates were randomly assigned to receive either vehicle (PBS) or ghrelin ( $0.5 \mathrm{mg}$ per kg body weight in PBS, Phoenix Pharmaceuticals). Ghrelin dosage was determined based on previously published experiments in mice (Wang et al., 2002; Ueno et al., 2004). Each mouse was lightly restrained and given a single intraperito- 
A

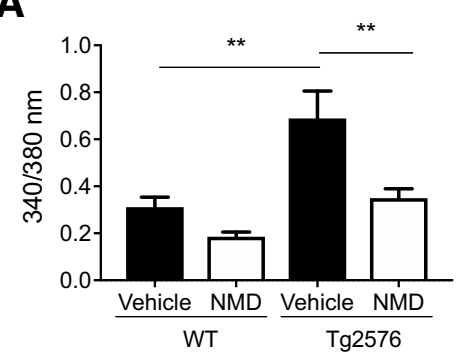

B

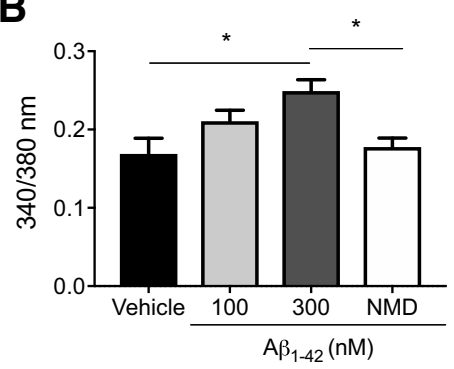

Figure 2. Arcuate NPY neurons from Tg2576 brain slices or exogenous $A \beta_{1-42}$-treated WT brain slices have increased cytoplasmic-free $\mathrm{Ca}^{2+}$ levels that can be reversed by the $\mathrm{L}$-type $\mathrm{Ca}^{2+}$ channel blocker nimodipine (NMD). $\boldsymbol{A}$, Arcuate NPY neurons from Tg2576 mice have increased cytoplasmic-free $\mathrm{Ca}^{2+}$ levels compared with WT mice that are decreased by nimodipine. Cytoplasmic-free $\mathrm{Ca}^{2+}$ was measured using fura-2 AM in arcuate NPY neurons isolated by enzymatic digestion from WT or Tg2576 mice. After obtaining baseline levels, cells were perfused with nimodipine $(2 \mu \mathrm{M}) . n=18-21$ cells from $\geq 3$ mice per group. Statistical analysis: one-way ANOVA $\left(F_{(3,74)}=9.738, p<0.0001\right.$, followed by post hoc Tukey's multiple comparisons). ${ }^{* *} p<$ 0.01. $B$, Exogenous $A \beta_{1-42}$-treated arcuate NPY neurons from WT mice have increased cytoplasmic-free $\mathrm{Ca}^{2+}$ levels that are decreased by nimodipine. Cytoplasmic-free $\mathrm{Ca}^{2+}$ was measured using fura- $2 \mathrm{AM}$ in arcuate NPY neurons isolated by enzymatic digestion from WT mice. After obtaining baseline levels, cells were first perfused with oligomeric $A \beta_{1-42}(100$ or $300 \mathrm{~nm})$ followed by nimodipine $(2 \mu \mathrm{M}) . n=4$ or 5 cells from 2 mice per group. Statistical analysis: one-way ANOVA $\left(F_{(3,14)}=5.028, p=0.0143\right.$, followed by post hoc Tukey's multiple comparisons). ${ }^{*} p<0.05$. Data are mean \pm SEM.

neal injection of PBS or ghrelin $3 \mathrm{~h}$ into the light cycle, when mice are in a satiated state. Immediately after the injection, each mouse was individually housed in a standard cage with free access to water and a premeasured standard rodent chow (LabDiet, catalog \#5053). One hour after the injection, food intake was measured with the cage carefully inspected to ensure there were no missing or spilled pellets. After the experiment, mice were group housed with the same littermates as before. One week later, mice that had been given previously PBS received ghrelin, and those that were given ghrelin received PBS injections. Food intake was measured as before. For the nimodipine pretreatment experiment, 3- to 5 -month-old mice were first administered a single intraperitoneal injection of nimodipine $(10 \mathrm{mg}$ per $\mathrm{kg}$ body weight in $2 \%$ DMSO and PBS, Sigma-Aldrich). Thirty minutes after the nimodipine injection, mice were randomly given an intraperitoneal bolus injection of either ghrelin (0.5 mg per $\mathrm{kg}$ body weight in PBS) or PBS alone. Food intake was measured as before. The following week, all mice were pretreated as before with nimodipine, those that received PBS the prior week received ghrelin, and those that received ghrelin received PBS. Experiments were repeated in 10-month-old Tg2576 and WT littermate mice. Since adult male Tg2576 mice have to be single-housed at all times due to aggressive behavior, female mice were used in all feeding experiments to minimize any confounding effects caused by stress due to prolonged social isolation. The food intake measured was normalized to the body weight (per $100 \mathrm{~g}$ ) of each mouse to minimize any variations due to differences in body weight as Tg2576 mice as a group have lower body weight compared with WT littermates throughout adulthood (Ishii et al., 2014).

Experimental design and statistical analyses. Experiments were designed to determine changes associated with experimental manipulations (e.g., vehicle and drug) and/or genotype (i.e., Tg2576 mice compared with WT littermate mice). Unless otherwise indicated, all data are presented as mean \pm SEM and analyzed using Prism version 8 (GraphPad Software). Two-group comparisons were analyzed by the two-tailed unpaired Student's $t$ test. Two-tailed paired Student's $t$ test was used for comparisons between two different treatments (i.e., vehicle and drug) used in the same cell or mouse. Multiple three or more group comparisons were evaluated by one-way or two-way ANOVA followed by post hoc Tukey or Sidak's test for multiple comparisons. Differences were considered statistically significant for $p$ values $<0.05$.

\section{Results}

Arcuate NPY neurons from Tg2576 mice exhibit nimodipinesensitive changes in membrane potential and spike frequency Using whole-cell current-clamp recordings, we investigated the electrophysiological properties of arcuate NPY neurons in

brain slices of Tg2576 mice expressing GFP in NPY neurons (Ishii et al., 2014). Since voltage-gated $\mathrm{Ca}^{2+}$ channels are involved in $\mathrm{A} \beta$-mediated intracellular $\mathrm{Ca}^{2+}$ dysregulation in other systems (Mattson, 2007; Alzheimer's Association Calcium Hypothesis Workgroup, 2017; Frere and Slutsky, 2018), we tested whether these channels could be responsible for the aberrant electrophysiological properties of arcuate NPY neurons in Tg2576 brain slices. The L-type $\mathrm{Ca}^{2+}$ channel antagonist nimodipine $(2 \mu \mathrm{M})$ significantly hyperpolarized the membrane potential and lowered the spike frequency in arcuate NPY neurons from Tg2576 slices (Fig. $1 A-C)$; however, antagonists against other types of voltage-gated $\mathrm{Ca}^{2+}$ channels, such as $\omega$-Cgtx-GVIA $(1 \mu \mathrm{M})$ and $\omega$-AgaIVA ( $1 \mu \mathrm{M})$, which respectively block N-type and P/Q-type $\mathrm{Ca}^{2+}$ channels, had no effect (Fig. $1 D, E$ ).

Arcuate NPY neurons from Tg2576 mice exhibit nimodipinesensitive increases in cytoplasmic $\mathrm{Ca}^{2+}$ levels

Since the electrical activities in Tg2576 arcuate NPY neurons were sensitive to the L-type $\mathrm{Ca}^{2+}$ channel blocker nimodipine, we next used fura-2 AM to image and quantitate cytoplasmic-free $\mathrm{Ca}^{2+}$ levels in dissociated arcuate NPY neurons identified by GFP. Arcuate NPY neurons from Tg2576 mice had higher cytoplasmic-free $\mathrm{Ca}^{2+}$ levels at baseline compared with those from WT mice (Fig. 2A). Incubation with nimodipine $(2 \mu \mathrm{M})$ decreased cytoplasmic-free $\mathrm{Ca}^{2+}$ levels in arcuate NPY neurons from Tg2576 mice but not in WT mice (Fig. 2A). Next, we incubated arcuate NPY neurons dissociated from WT mice with oligomeric $\mathrm{A} \beta_{1-42}(100 \mathrm{nM})$ and found a significant dose-related increase in cytoplasmic-free $\mathrm{Ca}^{2+}$ levels that was reversed by nimodipine (Fig. 2B).

\section{The peak L-type $\mathrm{Ca}^{2+} \mathrm{I}-V$ curve of arcuate NPY neurons from} Tg2576 mice is shifted to the left

Due to the increased cytoplasmic-free $\mathrm{Ca}^{2+}$ levels and altered activity in arcuate NPY neurons from Tg2576 and WT slices treated with $\mathrm{A} \beta_{1-42}$, we next sought to examine the role of $\mathrm{Ca}^{2+}$ currents in these neurons. Using whole-cell voltage-clamp recordings, voltage-gated calcium currents were elicited in the presence of the $\mathrm{Na}^{+}$channel blocker TTX $(1 \mu \mathrm{M})$ and the N-type $\mathrm{Ca}^{2+}$ channel blocker $\omega$-Cgtx-GVIA $(1 \mu \mathrm{M})$ (Fig. $3 A$ ). Interestingly, there was a left shift in the peak L-type $\mathrm{Ca}^{2+}$ current $I-V$ curve of arcuate NPY neurons from Tg2576 brain slices compared with WT slices (Fig. 3B), an effect also observed in arcuate NPY neurons of WT slices incubated with oligomeric $\mathrm{A} \beta_{1-42}(100 \mathrm{~nm})$ (Fig. $3 C$ ). The left shift in the $I-V$ curves suggests a propensity for L-type $\mathrm{Ca}^{2+}$ channels to open at a lower voltage threshold, closer to the resting membrane potentials, resulting in increased $\mathrm{Ca}^{2+}$ influx into the neurons. Nimodipine $(2 \mu \mathrm{M})$ blocked L-type $\mathrm{Ca}^{2+}$ currents at $-10 \mathrm{mV}$ in NPY neurons from brain slices of Tg2576 mice as well as WT brain slices incubated with oligomeric $\mathrm{A} \beta_{1-42}$. (Fig. 3D). 
CaMKII and $\mathrm{IP}_{3}$ inhibitors can partially reverse the left shift in the L-type $\mathrm{Ca}^{2+}$ current $I-V$ curve of arcuate NPY neurons from $\mathrm{Tg} 2576$ mice

To gain initial insight into the signaling pathways contributing to the $\mathrm{A} \beta$-mediated changes in L-type $\mathrm{Ca}^{2+}$ currents, we investigated whether common modulators of intracellular $\mathrm{Ca}^{2+}$ signaling were involved (Gao et al., 2006; Zamponi et al., 2015; Zamponi,

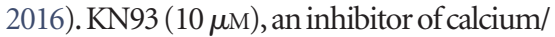
calmodulin-dependent kinase II (CaMKII), and $2 \mathrm{APB}(50 \mu \mathrm{M})$, an inhibitor of $\mathrm{IP}_{3}$ and transient receptor potential channels, partially reversed the left shift in the peak L-type $\mathrm{Ca}^{2+}$ current $I-V$ curve of $T g 2576$ slices, but the phospholipase C inhibitor U733122 (10 $\mu \mathrm{M})$ had no effect (Fig. $4 A-C$ ). This observation suggests that the intracellular $\mathrm{Ca}^{2+}$ dyshomeostasis in arcuate NPY neurons caused by $\mathrm{A} \beta$ is mediated in part through CaMKII and $\mathrm{IP}_{3}$-dependent mechanisms.

\section{Ghrelin and leptin fail to modulate cytoplasmic $\mathrm{Ca}^{2+}$ levels in arcuate NPY neurons of $\mathrm{Tg} 2576$ mice}

Next, we tested whether a known activator (ghrelin) and inhibitor (leptin) of arcuate NPY neurons could modulate cytoplasmic-free $\mathrm{Ca}^{2+}$ levels in these neurons from WT and Tg2576 mice (McGuire and Ishii, 2016; Yanagi et al., 2018). Using $\mathrm{Ca}^{2+}$ imaging in arcuate NPY neurons dissociated from WT mice, we found that ghrelin (100 nm) increased the cytoplasmic-free $\mathrm{Ca}^{2+}$ levels (Fig. 5A). However, ghrelin had no effect on cytoplasmic-free $\mathrm{Ca}^{2+} \mathrm{lev}$ els of arcuate NPY neurons from Tg2576 mice (Fig. 5A). Similarly, leptin (100 nM) decreased the cytoplasmic-free $\mathrm{Ca}^{2+}$ levels in WT, but not in Tg2576 arcuate NPY neurons (Fig. 5B). We then sought to determine whether leptin regulates cytoplasmic-free $\mathrm{Ca}^{2+}$ levels in these neurons through L-type $\mathrm{Ca}^{2+}$ channels. Using whole-cell voltageclamp recordings, we found that leptin decreased the peak L-type $\mathrm{Ca}^{2+}$ current amplitudes in WT, but not in Tg2576 arcuate NPY neurons (Fig. 5C,D), attesting to the leptin insensitivity of these neurons.

$A \boldsymbol{\beta}_{1-42}$ attenuates the neurophysiological responses to ghrelin in arcuate NPY neurons from WT mice, an effect mediated by L-type $\mathrm{Ca}^{2+}$ channels Since the neurophysiological responses to ghrelin were attenuated in Tg2576 arcuate NPY neurons, we examined whether $\mathrm{A} \beta_{1-42}$ mediated this effect by L-type $\mathrm{Ca}^{2+}$ channels. Using whole-cell current-clamp re-
A

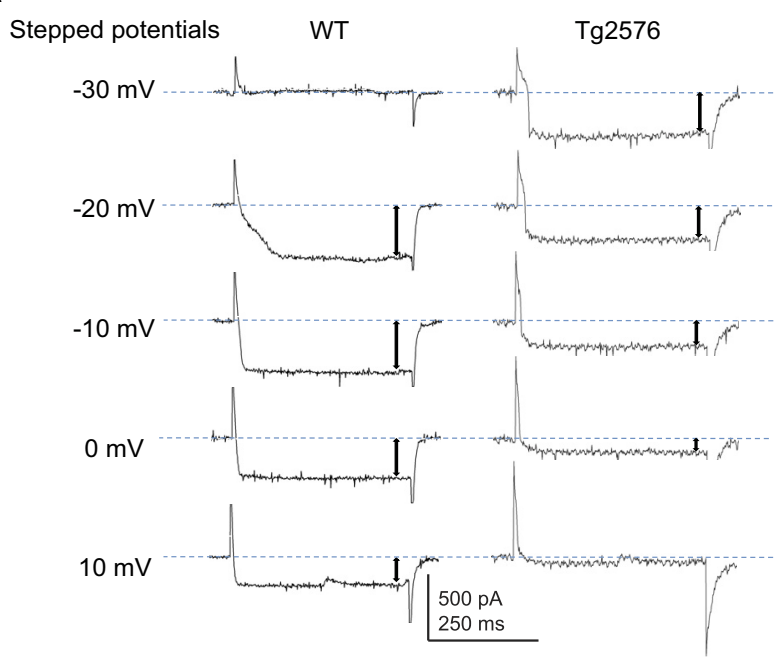

B

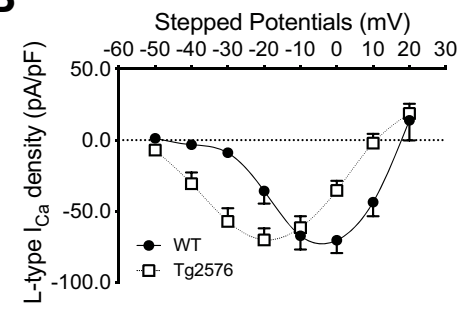

C

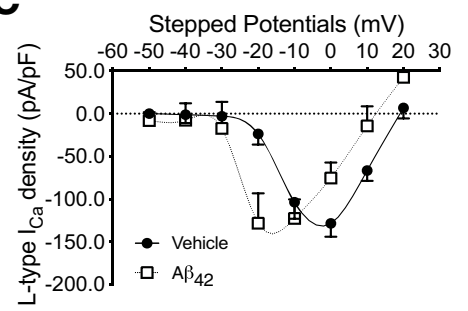

D

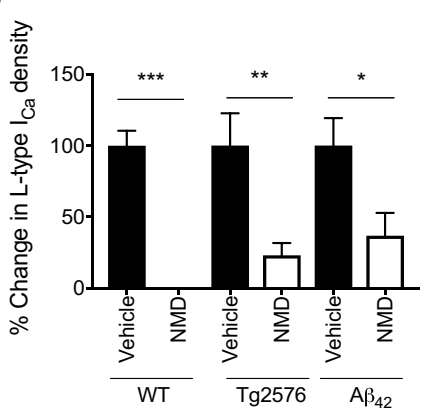

Figure 3. Arcuate NPY neurons from Tg2576 brain slices or exogenous $A \beta_{1-42}$-treated WT brain slices have a left shift in the peak L-type $\mathrm{Ca}^{2+}$ current $I-V$ curve that can be reversed by the $\mathrm{L}$-type $\mathrm{Ca}^{2+}$ channel blocker nimodipine (NMD). $A, \mathrm{~L}$-type $\mathrm{Ca}^{2+}$ currents in arcuate NPY neurons from Tg2576 brain slices show a propensity for channel opening close to the resting potential compared with arcuate NPY neurons from WT brain slices. Representative traces are shown using the holding potential $-60 \mathrm{mV}$ to different stepped potentials from -50 to $20 \mathrm{mV}$ (showing -30 to $10 \mathrm{mV}$ ). B, I-V relationships for L-type $\mathrm{Ca}^{2+}$ currents in arcuate NPY neurons from WT or Tg2576 brain slices. There was a left shift in the peak L-type $\mathrm{Ca}^{2+}$ current $/-V$ curve in arcuate NPY neurons from Tg2576 brain slices compared with WT brain slices. The peak L-type $\mathrm{Ca}^{2+}$ current in the $I-V$ curve occurred at -20 $\mathrm{mV}$ for arcuate NPY neurons from Tg2576 brain slices compared with $0 \mathrm{mV}$ for arcuate NPY neurons from WT slices. At $-20 \mathrm{mV}$, arcuate NPY neurons from Tg2576 brain slices have significantly higher L-type $\mathrm{Ca}^{2+}$ currents compared with arcuate NPY neurons from WT brain slices. Data are represented as L-type $\mathrm{Ca}^{2+}$ current density (pA/pF). $n=19-27$ per group from $\geq 12$ mice per group. Statistical analysis: two-tailed unpaired Student's t test $(t=2.832, \mathrm{df}=45, p=0.0069)$. C, The peak L-type $\mathrm{Ca}^{2+}$ current $I-V$ curve in arcuate NPY neurons from WT brain slices treated with oligomeric $A \beta_{1-42}(100 \mathrm{nM})$ recapitulates the left shift seen in arcuate NPY neurons from Tg2576 brain slices. The peak L-type $\mathrm{Ca}^{2+}$ current in the $I-V$ curve occurred between $-10 \mathrm{mV}$ and -20 $\mathrm{mV}$ for arcuate NPY neurons after application of oligomeric $A \beta_{1-42}(100 \mathrm{~nm})$ slices compared with $0 \mathrm{mV}$ at baseline (vehicle treatment). At $-20 \mathrm{mV}$, arcuate NPY neurons from oligomeric $A \beta_{1-42}(100 \mathrm{nM})$-treated WT brain slices have significantly higher L-type $\mathrm{Ca}^{2+}$ currents compared with arcuate NPY neurons from vehicle-treated WT brain slices. Data are represented as L-type $\mathrm{Ca}^{2+}$ current density $(\mathrm{pA} / \mathrm{pF}) . n=6$ per group from $\geq 4$ mice per group. Statistical analysis: two-tailed paired Student's $t$ test $(t=4.598, \mathrm{df}=5, p=0.0059)$. D, L-type $\mathrm{Ca}^{2+}$ current induced at $-10 \mathrm{mV}$ were significantly decreased after application of nimodipine $(2 \mu \mathrm{M})$ in arcuate NPY neurons from WT brain slices, Tg2576 brain slices, and WT brain slices treated with oligomeric $\mathrm{A} \beta_{1-42}(100 \mathrm{~nm}) . n=5-8$ per group from $\geq 4$ mice per group. Statistical analysis: two-tailed paired Student's $t$ test (WT: $t=$ $\left.9.806, \mathrm{df}=7, p<0.0001 ; \operatorname{Tg} 2576: t=4.694, \mathrm{df}=5, p=0.0054 ; \mathrm{A} \beta_{1-42}: t=2.912, \mathrm{df}=4, p=0.0436\right)$. Data are mean \pm SEM. ${ }^{*} p<0.05$. ${ }^{* *} p<0.01$. ${ }^{* * *} p<0.001$. 
A

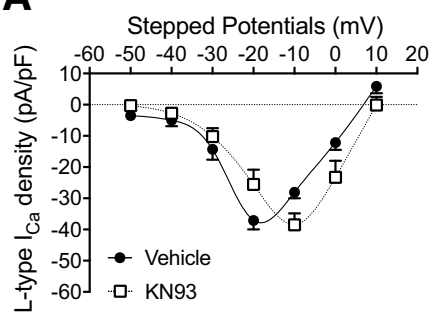

B

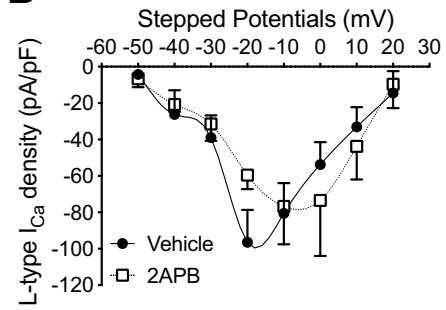

C

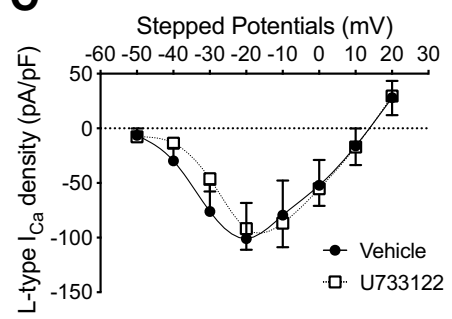

Figure 4. Pharmacologic inhibition of CaMKII or IP $\mathrm{P}_{3}$ can partially reverse the left shift in the peak L-type $\mathrm{Ca}^{2+}$ current $I-V$ curve in arcuate NPY neurons from Tg2576 brain slices. $A$, $I-V$ relationships for L-type $\mathrm{Ca}^{2+}$ currents in arcuate NPY neurons from Tg2576 brain slices after application of the CaMKII antagonist KN93 (10 $\left.\mu \mathrm{M}\right)$. The left-shifted $I-V$ curve was partially reversed after application of KN93. The peak L-type $\mathrm{Ca}^{2+}$ current in the $\mathrm{I}-V$ curve occurred at $-20 \mathrm{mV}$ for arcuate NPY neurons from vehicle-treated Tg2576 brain slices compared with $-10 \mathrm{mV}$ after KN93 application. At $-20 \mathrm{mV}$, arcuate NPY neurons from KN93 (10 $\mu \mathrm{M})$-treated Tg2576 brain slices have significantly lower L-type $\mathrm{Ca}^{2+}$ currents compared with vehicle-treated Tg2576 brain slices. Data are represented as L-type $\mathrm{Ca}^{2+}$ current density (pA/pF). $n=5$ per group from 4 mice per group. Statistical analysis: two-tailed paired Student's $t$ test $(t=2.854, \mathrm{df}=4, p=0.0462) . B, I-V$ relationships for L-type $\mathrm{Ca}^{2+}$ currents in arcuate NPY neurons from Tg2576 brain slices after application of the IP ${ }_{3}$ antagonist 2 APB $(50 \mu \mathrm{M})$. The left-shifted $I-V$ curve was partially reversed after application of $2 \mathrm{APB}$. The peak L-type $\mathrm{Ca}^{2+}$ current in the $I-V$ curve 0 ccurred at $-20 \mathrm{mV}$ for arcuate NPY neurons from Tg2576 brain slices compared with $-10 \mathrm{mV}$ after $2 \mathrm{APB}$ application. At $-20 \mathrm{mV}$, arcuate NPY neurons from $2 \mathrm{APB}(50 \mu \mathrm{m})$-treated Tg2576 brain slices have significantly lower L-type $\mathrm{Ca}^{2+}$ currents compared with vehicle-treated Tg2576 brain slices. Data are represented as L-type $\mathrm{Ca}^{2+}$ current density (pA/pF). $n=4$ per group from 3 mice per group. Statistical analysis: two-tailed paired Student's $t$ test $(t=3.656, \mathrm{df}=3, p=0.0353) . C, I-V$ relationships for L-type $\mathrm{Ca}^{2+}$ currents in arcuate NPY neurons from Tg2576 brain slices after application of the phospholipase C antagonist U733122 (10 $\mu \mathrm{M})$. The left-shifted $I-V$ curve was unchanged after application of U733122. The peak $\mathrm{L}$-type $\mathrm{Ca}^{2+}$ current in the $I-V$ curve occurred at $-20 \mathrm{mV}$ for arcuate NPY neurons from Tg2576 brain slices before and after U733122 application. At $-20 \mathrm{mV}$, arcuate NPY neurons from U733122 (10 $\mu \mathrm{m}$ )-treated Tg2576 brain slices have similar L-type $\mathrm{Ca}^{2+}$ currents compared with vehicle-treated Tg2576 brain slices. $n=5$ cells per group from 3 mice per group. Statistical analysis: two-tailed paired Student's $t$ test $(t=0.3566, \mathrm{df}=4, p=0.7394)$. Data are mean \pm SEM.

A

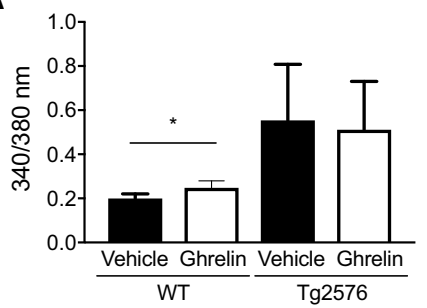

C

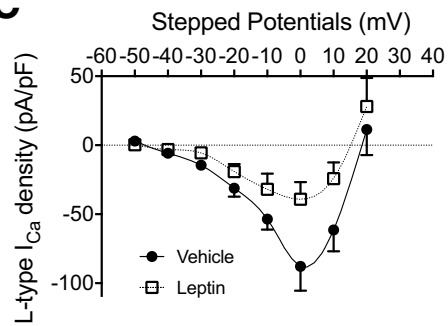

B

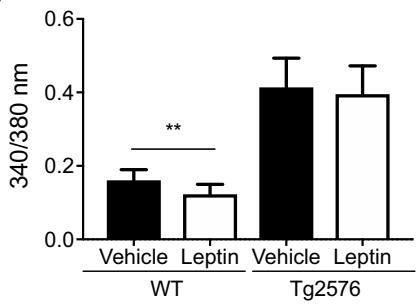

D

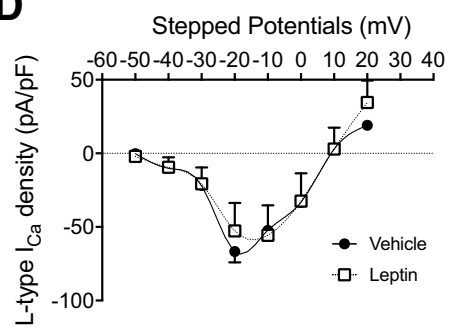

Figure 5. Ghrelin and leptin fail to modulate cytoplasmic-free $\mathrm{Ca}^{2+}$ levels in arcuate NPY neurons from Tg2576 mice. A, Ghrelin increases cytoplasmic-free $\mathrm{Ca}^{2+}$ levels in arcuate NPY neurons from WT but not Tg2576 mice. Cytoplasmic-free $\mathrm{Ca}^{2+}$ was measured using fura-2 AM in arcuate NPY neurons isolated by enzymatic digestion from WT or Tg2576 mice. After obtaining baseline levels, cells were perfused with ghrelin (100 nM). $n=34$ WT and $n=7 \mathrm{Tg} 2576$ cells from $\geq 3$ mice per group. Statistical analysis: two-tailed paired Student's $t$ test (WT: $t=2.664, \mathrm{df}=34, p=0.0117 ; \operatorname{Tg} 2576: t=1.020$, $\mathrm{df}=7, p=0.3471) . B$, Leptin decreases cytoplasmic-free $\mathrm{Ca}^{2+}$ levels in arcuate NPY neurons from WT but not Tg2576 mice. Cytoplasmic-free $\mathrm{Ca}^{2+}$ was measured using fura-2 AM in arcuate NPY neurons isolated by enzymatic digestion from WT or Tg2576 mice. After obtaining baseline levels, cells were perfused with leptin (100 nM). $n=25$ WT and $n=20 \mathrm{Tg} 2576$ cells from $\geq 3$ mice per group. Statistical analysis: two-tailed paired Student's $t$ test (WT: $t=3.032, \mathrm{df}=24, p=0.0057$; Tg2576: $t=2.030, \mathrm{df}=19, p=0.0566) . C, I-V$ relationships for L-type $\mathrm{Ca}^{2+}$ currents in arcuate NPY neurons from WT brain slices after application of leptin (100 nm). Compared with vehicle treatment, leptin significantly decreased the peak L-type $\mathrm{Ca}^{2+}$ current at $0 \mathrm{mV}$. Data are represented as L-type $\mathrm{Ca}^{2+}$ current density $(\mathrm{pA} / \mathrm{pF}) . n=7$ cells per group. Statistical analysis at $0 \mathrm{mV}$ : two-tailed paired Student's $t$ test $(t=3.601, \mathrm{df}=6, p=0.0114)$. $\boldsymbol{D}, I-V$ relationships for L-type $\mathrm{Ca}^{2+}$ currents in arcuate NPY neurons from Tg2576 brain slices after application of leptin ( $100 \mathrm{~nm}$ ). Compared with vehicle treatment, there is no significant difference in L-type $\mathrm{Ca}^{2+}$ currents. Data are represented as L-type $\mathrm{Ca}^{2+}$ current density (pA/pF). $n=4$ cells per group. Statistical analysis at $-20 \mathrm{mV}$ : two-tailed paired Student's $t$ test $(t=1.379, \mathrm{df}=$ $3, p=0.2617)$. Data are mean \pm SEM. ${ }^{*} p<0.05 .{ }^{* *} p<0.01$.

cordings ghrelin could significantly depolarize the membrane potential and increase the spike frequency in WT arcuate NPY neurons, an effect that was attenuated when preincubated with oligomeric $\mathrm{A} \beta_{1-42}(100 \mathrm{~nm})$ (Fig. 6A, B). Incubation with nimodipine $(2 \mu \mathrm{M})$ restored the effects of ghrelin on the membrane potentials (Fig. 6A,B). Similarly, using $\mathrm{Ca}^{2+}$ imaging in arcuate NPY neurons dissociated from WT mice, the increased cytoplasmic-free $\mathrm{Ca}^{2+}$ levels mediated by ghrelin were attenuated when preincubated with oligomeric $\mathrm{A} \beta_{1-42}(100 \mathrm{nM})$ and subsequently restored with nimodipine $(2 \mu \mathrm{M})$ (Fig. $6 C$ ).

\section{Ghrelin induces feeding behavior in WT, but not in Tg2576 mice, an effect mediated by L-type $\mathrm{Ca}^{2+}$ channels} We next tested whether the acute orexigenic effect of ghrelin, which is mediated by arcuate NPY neurons, was also altered in Tg2576 mice in vivo. Using a randomized controlled crossover design, young (3- to 5-month old) female Tg2576 and WT littermate mice were injected with a single bolus of ghrelin $(0.5 \mathrm{mg}$ per kg body weight, i.p.) or vehicle (PBS) in the first week and then switched to vehicle or ghrelin as appropriate in the second week. As expected, WT mice had an acute increase in food intake after ghrelin injection; however, Tg2576 mice had no significant increase in food intake after ghrelin injection (Fig. 7A). We then examined whether nimodipine, which readily crosses the 
A

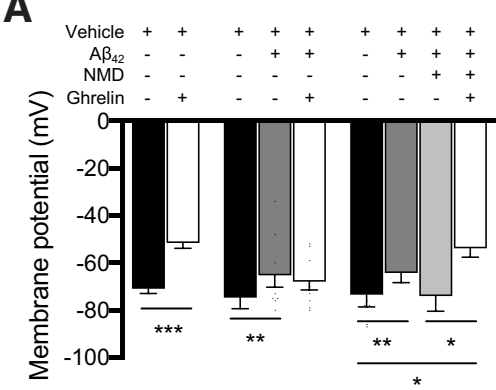

B
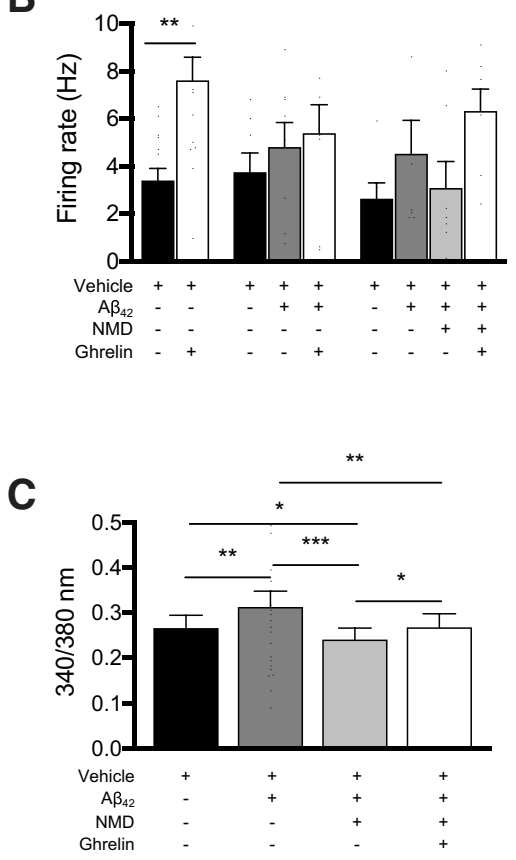

Figure 6. Nimodipine can restore the neurophysiological responses to ghrelin in arcuate NPY neurons treated with oligomeric $A \beta_{1-42} . A, B$, Brain slices containing hypothalamic arcuate nucleus from young (3- to 4-month-old) NPY-GFP mice were used for whole-cell patch-clamp recordings. Application of ghrelin $(100 \mathrm{~nm})$ depolarized the membrane potential and increased spike frequency of arcuate NPY neurons. Exogenous oliogmeric $A \beta_{1-42}(100 \mathrm{~nm})$ depolarized the membrane potential of arcuate NPY neurons and inhibited its response to ghrelin (100 nM). Nimodipine (NMD, $2 \mu \mathrm{M}$ ) restored the ghrelin-mediated depolarization of arcuate NPY neurons treated with exogenous oligomeric $A \beta_{1-42}$. Statistical analysis: two-tailed paired Student test for comparison of vehicle to ghrelin-treated arcuate NPY neurons (membrane potential: $t=$ $6.444, \mathrm{df}=15, p<0.001, n=16$ cells from 13 mice per group; spike frequency: $t=3.742$, $\mathrm{df}=13, p=0.0025, n=14$ cells from 12 mice per group). Repeated-measures one-way ANOVA comparing vehicle, $A \beta_{1-42}$, and ghrelin treatments (membrane potential: $F_{(1.579,12.63)}=7.577$, $p=0.0096, n=9$ cells from 5 mice per group; spike frequency: $F_{(1.365,9.557)}=3.941, p=$ $0.0679, n=8$ cells from 5 mice per group), followed by post hoc Tukey's multiple comparisons. Repeated-measures one-way ANOVA comparing vehicle, $A \beta_{1-42}$, nimodipine, and ghrelin treatments (membrane potential: $F_{(1.883,11.30)}=8.785, p=0.0014, n=7$ cells from 4 mice per group; spike frequency: $F_{(2.125,12.75)}=3.220, p=0.0716, n=7$ cells from 4 mice per group) followed by post hoc Tukey's multiple comparisons. ${ }^{*} p<0.05 .{ }^{* *} p<0.01$. ${ }^{* * *} p<$ 0.001. Data are mean \pm SEM. C, Nimodipine restored the ghrelin-mediated increase in cytoplasmic-free $\mathrm{Ca}^{2+}$ levels in arcuate NPY neurons treated with exogenous oligomeric $A \beta_{1-}$ 42. Cytoplasmic-free $\mathrm{Ca}^{2+}$ was measured using fura-2 AM in arcuate NPY neurons isolated by enzymatic digestion from young (3- to 4-month-old) WT NPY-GFP mice. After obtaining baseline levels, cells were perfused sequentially with oligomeric $A \beta_{1-42}(100 \mathrm{nM})$, nimodipine (2 $\mu \mathrm{M})$, and then ghrelin (100 nM). Statistical analysis: repeated-measures one-way ANOVA comparing vehicle, $A \beta_{1-42}$, nimodipine, and ghrelin treatments $\left(F_{(2.128,44.69)}=13.90, p<\right.$ $0.0001, n=22$ cells from 4 mice) followed by post hoc Tukey's multiple comparisons. ${ }^{*} p<$ 0.05 . ${ }^{* *} p<0.01$. ${ }^{* * *} p<0.001$. Data are mean \pm SEM. blood-brain barrier (Ingwersen et al., 2018), could restore the acute orexigenic effects of ghrelin in the young Tg2576 mice. Pretreatment with nimodipine (10 mg per kg body weight, i.p.) led to a robust increase in food intake after ghrelin injection in Tg2576 mice that were similar to those seen in WT littermates, suggesting that blocking L-type $\mathrm{Ca}^{2+}$ channels could restore the orexigenic pathways in vivo in the Tg2576 mice (Fig. 7B). However, pretreatment of nimodipine did not restore the effects of ghrelin on feeding behavior in 10-month-old Tg2576 mice (Fig. 7C).

Hypothalamic neurons in the paraventricular nucleus from Tg2576 mice do not have increased cellular activity and have no change in L-type $\mathrm{Ca}^{2+}$ currents

Next, we sought to determine whether $A \beta$-mediated intracellular $\mathrm{Ca}^{2+}$ dysregulation is a general pathological process affecting all hypothalamic neurons. To this end, we selected random hypothalamic neurons in the paraventricular nucleus from WT and Tg2576 mice to determine whether these neurons were similarly affected as arcuate NPY neurons. Using whole-cell voltage clamp, we found that $\mathrm{Tg} 2576$ paraventricular hypothalamic neurons display baseline electrophysiological properties similar to those of WT mice and no changes in the amplitudes or the peak L-type $\mathrm{Ca}^{2+}$ current $I-V$ curve (Fig. 8).

\section{Discussion}

We investigated the cellular mechanisms underlying how $\mathrm{A} \beta$ mediates dysfunction of hypothalamic neurons that are essential for the regulation of body weight. Our prior studies had found that overexpression of APP or application of oligomeric $A \beta_{1-42}$ in arcuate NPY neurons depolarized the membrane potential resulting in a lack of neurophysiological response to positive (ghrelin) and negative (leptin) modulators (Ishii et al., 2014). In this study, we found that the L-type $\mathrm{Ca}^{2+}$ channel antagonist nimodipine hyperpolarized the membrane potential, decreased the spike frequency, and reduced the intracellular $\mathrm{Ca}^{2+}$ levels due to overexpression of APP in arcuate NPY neurons. Furthermore, compared with arcuate NPY neurons from WT slices, there was a left shift in the peak L-type $\mathrm{Ca}^{2+}$ current $I-V$ curve in arcuate NPY neurons from Tg2576 slices, an effect recapitulated in WT slices treated with oligomeric $A \beta_{1-42}$. This left shift in the peak L-type $\mathrm{Ca}^{2+}$ current $I-V$ curve suggests that $\mathrm{A} \beta$ can alter the L-type $\mathrm{Ca}^{2+}$ influx in arcuate NPY neurons to one that is lowvoltage threshold activated with an increased propensity of channel opening around the resting membrane potential, leading to more frequent firing and disruption of intracellular $\mathrm{Ca}^{2+}$ homeostasis. These effects were due in part to CaMKII and $\mathrm{IP}_{3}$ dependent mechanisms. We further show evidence that leptin can decrease, whereas ghrelin can increase, cytoplasmic-free $\mathrm{Ca}^{2+}$ levels in arcuate NPY neurons from WT mice but not in $\mathrm{Tg} 2576$ mice. In vivo, pretreatment with nimodipine restored the acute hyperphagic effects of ghrelin in young (3-5 months), but not older (10 months), Tg2576 mice. Finally, not all hypothalamic neurons are affected, as paraventricular neurons from Tg2576 mice have L-type $\mathrm{Ca}^{2+}$ currents similar to those of WT mice. Together, these observations provide, for the first time, evidence that $\mathrm{A} \beta$ disrupts intracellular $\mathrm{Ca}^{2+}$ homeostasis and neurophysiological characteristics of select hypothalamic neurons by shifting from a high-threshold to a low-threshold activated L-type $\mathrm{Ca}^{2+}$ current. 
A

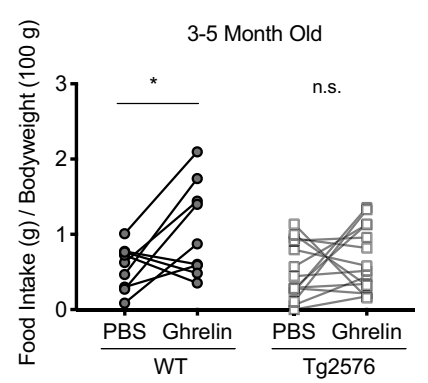

B

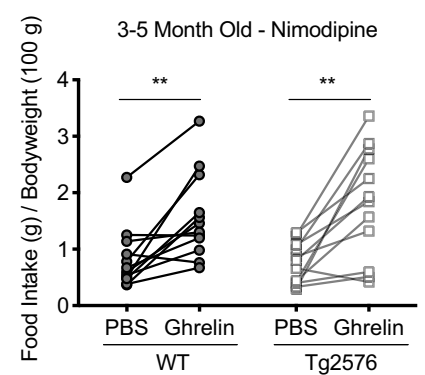

C

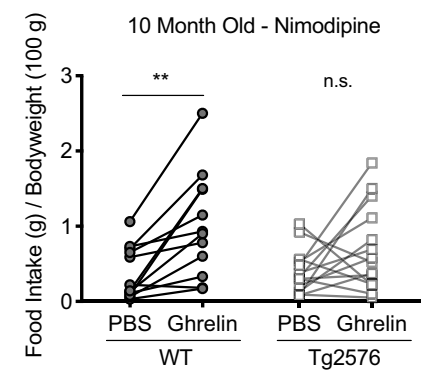

Figure 7. Pretreatment with nimodipine can restore ghrelin-mediated feeding behavior in young ( $3-5$ months), but not older (10 months), Tg2576 mice. $A$, Ghrelin ( 0.5 mg per kg body weight, i.p.) increased feeding in young ( $3-5$ months) WT but not Tg2576 mice. $n=9$ WT and $n=14 \operatorname{Tg} 2576$ mice. Statistical analysis: two-tailed paired Student's test (WT: $t=2.337, \mathrm{df}=8, p=0.0476$; $\operatorname{Tg} 2576: t=1.034, \mathrm{df}=13, p=0.3201) . \boldsymbol{B}$, Nimodipine (10 mg per kg body weight, i.p.) administered $1 \mathrm{~h}$ before ghrelin ( $0.5 \mathrm{mg}$ per kg body weight, i.p.) restored the ghrelin-mediated feeding behavior in young (3-5 months) Tg2576 mice. $n=12 \mathrm{WT}$ and $n=12$ Tg2576 mice. Statistical analysis: two-tailed paired Student's $t$ test (WT: $t=3.986, \mathrm{df}=11, p=0.0021 ; \mathrm{Tg} 2576: t=4.284$, $\mathrm{df}=11, p=0.0013)$. C, Nimodipine (10 mg per kg body weight, i.p.) administered $1 \mathrm{~h}$ before ghrelin $(0.5 \mathrm{mg}$ per $\mathrm{kg}$ body weight, i.p.) failed to restore the ghrelin-mediated feeding behavior in older (10 months) Tg2576 mice. $n=12$ WT and $n=14$ Tg2576 mice. Statistical analysis: two-tailed paired Student's $t$ test (WT: $t=4.128, \mathrm{df}=11, p=0.0017 ; \mathrm{Tg} 2576: t=1.754, \mathrm{df}=13, p=$ 0.103). Data are expressed as individual mice. ${ }^{*} p<0.05 ;{ }^{* *} p<0.01$; paired $t$ test. n.s. $=$ not significant.

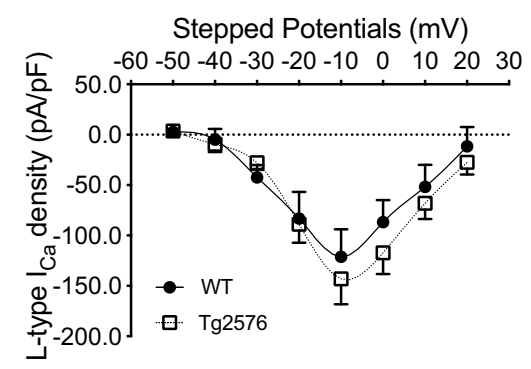

Figure 8. There are no significant differences in the $\mathrm{L}-t y p e \mathrm{Ca}^{2+}$ currents in hypothalamic paraventricular neurons from Tg2576 or WT mice. I-V curves for L-type $\mathrm{Ca}^{2+}$ currents in randomly selected hypothalamic paraventricular non-NPY neurons from WT or Tg2576 slices. There are no significant differences between hypothalamic paraventricular non-NPY neurons from WT and Tg2576 slices. The peak L-type $\mathrm{Ca}^{2+}$ current occurred at $-10 \mathrm{mV}$ for hypothalamic paraventricular neurons in both WT and Tg2576 brain slices with no significant differences in the amplitudes. Statistical analysis: two-tailed unpaired Student's $t$ test $(t=0.2289, \mathrm{df}=6$, $p=0.8266)$. Data are represented as L-type $\mathrm{Ca}^{2+}$ current density (pA/pF). $n=4$ cells per group from $\geq 3$ mice per group. Data are mean \pm SEM.

\section{A $\beta$-mediated intracellular $\mathrm{Ca}^{2+}$ dysregulation and the role of L-type $\mathrm{Ca}^{2+}$ channels}

Accumulating evidence supports the calcium hypothesis of AD, which postulates that the disruption of mechanisms that normally regulate intracellular $\mathrm{Ca}^{2+}$ signaling plays a critical role in triggering the neuronal dysfunction and driving $\mathrm{AD}$ pathogenesis (Alzheimer's Association Calcium Hypothesis Workgroup, 2017). Multiple mouse models of $A \beta$ pathology exhibit intracellular $\mathrm{Ca}^{2+}$ dyshomeostasis, including the Tg2576 mice (Lopez et al., 2008; Kastanenka et al., 2016). Furthermore, immunotherapy with aducanumab, an $\mathrm{A} \beta$ antibody developed for the treatment of $\mathrm{AD}$, restored intracellular $\mathrm{Ca}^{2+}$ in Tg2576 mice, strengthening the hypothesis that $\mathrm{A} \beta$ directly disrupts intracellular $\mathrm{Ca}^{2+}$ homeostasis (Kastanenka et al., 2016). However, the mechanisms of these effects have remained elusive. Early studies have implicated L-type $\mathrm{Ca}^{2+}$ channels as having a significant role in the $\mathrm{A} \beta$ mediated $\mathrm{Ca}^{2+}$ neurotoxicity particularly in cortical and hippocampal neurons (Weiss et al., 1994; Ueda et al., 1997; Fu et al., 2006). Additionally, whole-cell recordings from HEK293 cells recombinantly expressing L-type $\mathrm{Ca}^{2+}$ channels demonstrated that $\mathrm{A} \beta$ peptides can increase L-type $\mathrm{Ca}^{2+}$ currents (Scragg et al., 2005; Kim and Rhim, 2011). Here, we provided a mechanistic insight into this process by reporting that such $\mathrm{A} \beta$-induced $\mathrm{Ca}^{2+}$ dysregulation could be attributed to a shift from high to low voltage-threshold activated L-type $\mathrm{Ca}^{2+}$ currents.

Despite the significant evidence linking L-type $\mathrm{Ca}^{2+}$ channels to $\mathrm{A} \beta$-mediated $\mathrm{Ca}^{2+}$ neurotoxicity in cortical and hippocampal neurons, to the best of our knowledge, nothing was known about its effects on hypothalamic neurons. We present the first evidence that $\mathrm{A} \beta$ can cause intracellular $\mathrm{Ca}^{2+}$ dyshomeostasis in select hypothalamic neurons, which could be an underlying mechanism for the early metabolic and noncognitive manifestations of AD mediated by hypothalamic dysfunction (Ishii and Iadecola, 2015). Additionally, we show that overexpression of APP or oligomeric $\mathrm{A} \beta_{1-42}$ in arcuate NPY neurons can trigger a shift from high to low voltage-threshold-activated L-type $\mathrm{Ca}^{2+}$ currents, leading to an increase in intracellular $\mathrm{Ca}^{2+}$ levels. This results in neuronal hyperactivity that likely destabilizes the firing synchrony of these neurons and disrupts the network similar to the effects of $A \beta$ on hippocampal neurons (Frere and Slutsky, 2018; Zott et al., 2019). This effect appears to be selective since paraventricular neurons in the hypothalamus of $\mathrm{Tg} 2576$ mice were unaffected. However, it is likely that other neuronal populations are affected either independent of the arcuate NPY neuronal dysfunction or directly, such as the postsynaptic neurons in the parabrachial nucleus (Wu et al., 2009). Furthermore, the exact source of $\mathrm{A} \beta$ causing arcuate NPY neuronal dysfunction has not been elucidated. We have previously shown that APP overexpression can be detected in the hypothalamus of Tg2576 mice (Ishii et al., 2014); however, whether $A \beta$ is expressed directly in arcuate NPY neurons is not known. Ex vivo experiments with application of exogenous $\mathrm{A} \beta_{1-42}$ to WT slices suggest that $\mathrm{A} \beta$ does not need to be expressed in arcuate NPY neurons to cause dysfunction of these neurons. Finally, ghrelin-mediated feeding was restored in young $\mathrm{Tg} 2576$ mice after pretreatment with nimodipine, but importantly, nimodipine could not restore ghrelin function in older Tg2576 mice. Therefore, neuronal dysfunction caused by $\mathrm{Ca}^{2+}$ overload through L-type $\mathrm{Ca}^{2+}$ channels may be reversible only early in $A \beta$ pathology; however, it is unclear how early in the pathological process the dysfunction occurs.

How $\mathrm{A} \beta$ elicits a low voltage-threshold activated L-type $\mathrm{Ca}^{2+}$ current in arcuate NPY neurons remains elusive. Our studies did not specifically investigate the molecular mechanisms leading to this shift. L-type $\mathrm{Ca}^{2+}$ channels consist of five subunits with $\alpha_{1}$ subunit forming the main ion-conducting pore of the channel (Zamponi et al., 2015). There are two distinct L-type $\mathrm{Ca}^{2+}$ chan- 
nel $\alpha_{1}$ subunits identified in the brain, resulting in the two major isoforms $\mathrm{Ca}_{\mathrm{v}} 1.2$ and $\mathrm{Ca}_{\mathrm{v}} 1.3$ (Zamponi et al., 2015). A major electrophysiological distinction between $\mathrm{Ca}_{\mathrm{v}} 1.2$ and $\mathrm{Ca}_{\mathrm{v}} 1.3$ is that $\mathrm{Ca}_{\mathrm{v}} 1.3$ is activated at lower threshold potentials than $\mathrm{Ca}_{\mathrm{v}} 1.2$, triggering subthreshold depolarization, high intracellular $\mathrm{Ca}^{2+}$ levels, spontaneous firings, and synaptic transmission (Koschak et al., 2001; Xu and Lipscombe, 2001; Zamponi et al., 2015; Pinggera and Striessnig, 2016). Therefore, one possibility is that $\mathrm{A} \beta$ upregulates $\mathrm{Ca}_{\mathrm{v}} 1.3$ relative to $\mathrm{Ca}_{\mathrm{v}} 1.2$. Alternatively, there could be a shift in cellular localization of $\mathrm{Ca}_{\mathrm{v}} 1.3$, leading to a redistribution of the channel to the cell surface. This has been demonstrated in one study where the neurotoxic $A \beta_{25-35}$ fragment increased L-type $\mathrm{Ca}^{2+}$ currents by upregulating $\mathrm{Ca}_{\mathrm{v}} 1.3$ surface protein levels, whereas $\mathrm{Ca}_{\mathrm{v}} 1.3$ mRNA and total protein levels remained unchanged (Kim and Rhim, 2011). It has also been demonstrated that the short $\mathrm{Ca}_{\mathrm{v}} 1.3$ isoform, but not the long isoform, can associate to form cooperative clusters to help facilitate $\mathrm{Ca}^{2+}$ entry into neurons (Moreno et al., 2016). Therefore, $\mathrm{A} \beta$ could cause an increase in the short form of $\mathrm{Ca}_{\mathrm{v}} 1.3$, leading to increased $\mathrm{Ca}^{2+}$ influx and subsequent neurotoxicity. Alternatively, $\mathrm{A} \beta$ pathology could modify the $\mathrm{Ca}_{\mathrm{v}} 1.2$ protein, leading to changes in the electrophysiological properties of $\mathrm{Ca}_{\mathrm{v}} 1.2$ that make it appear more $\mathrm{Ca}_{\mathrm{v}} 1.3$-like. Future studies using genetic models will help to elucidate the contribution of $\mathrm{Ca}_{\mathrm{v}} 1.2$ and $\mathrm{Ca}_{\mathrm{v}} 1.3$ to $\mathrm{A} \beta$-mediated $\mathrm{Ca}^{2+}$ neurotoxicity.

Finally, the upstream mechanisms contributing to the $\mathrm{A} \beta$ mediated shift to low-threshold activated L-type $\mathrm{Ca}^{2+}$ currents in arcuate NPY neurons are not known, but our data suggest that they involve CaMKII and $\mathrm{IP}_{3}$-dependent pathways. Therefore, one hypothesis would be that $\mathrm{A} \beta$ first causes an increase in intracellular $\mathrm{Ca}^{2+}$ levels independent of L-type $\mathrm{Ca}^{2+}$ channels, such as through NMDA receptors, leading to activation of CaMKII and $\mathrm{IP}_{3}$ pathways. The activation of CaMKII and $\mathrm{IP}_{3}$ pathways could then in turn promote the switch to a low-threshold activated L-type $\mathrm{Ca}^{2+}$ current and further disruption of intracellular $\mathrm{Ca}^{2+}$ homeostasis by $\mathrm{Ca}^{2+}$-dependent facilitation in a positivefeedback mechanism.

\section{L-type $\mathrm{Ca}^{2+}$ channels and the regulation of body weight}

While the major focus of this study has been on understanding how $\mathrm{A} \beta$ pathology in the brain can lead to early systemic metabolic deficits, the results also highlight the role for L-type $\mathrm{Ca}^{2+}$ channels as modulators of arcuate NPY neuronal function and potential therapeutic targets in body weight disorders. Interestingly, L-type $\mathrm{Ca}^{2+}$ channels have been implicated in neuropsychiatric disorders, such as mood disorders that often have comorbid body weight disorders, suggesting a common molecular pathway linking these disorders (Treasure et al., 2015; Kabir et al., 2016). Therefore, modulation of L-type $\mathrm{Ca}^{2+}$ channels in hypothalamic neurons may serve as an important but underappreciated pathway for regulating body weight.

\section{Conclusion}

In conclusion, we have demonstrated that $\mathrm{A} \beta$ disrupts intracellular $\mathrm{Ca}^{2+}$ homeostasis in arcuate NPY neurons by shifting from normally high to low voltage-threshold activated L-type $\mathrm{Ca}^{2+}$ currents. While additional studies are needed to elucidate the exact molecular mechanisms and whether $\mathrm{A} \beta$ can similarly affect nonhypothalamic neurons, our findings suggest that $\mathrm{A} \beta$ disruption of arcuate NPY neurons may contribute to the weight loss seen in the earliest stages of AD. Furthermore, our finding, that the L-type $\mathrm{Ca}^{2+}$ channel blocker nimodipine can restore ghrelinmediated feeding in Tg2576 mice, suggests a therapeutic strategy against the early hypothalamic dysfunction caused by $\mathrm{A} \beta$. Finally, since L-type $\mathrm{Ca}^{2+}$ channels may play a significant role in neurological and psychiatric disorders ranging from autism to Parkinson's disease (Zamponi, 2016), elucidating the mechanisms causing alterations in the function of L-type $\mathrm{Ca}^{2+}$ channels in the brain could lead to a better understanding in the role of these channels in a variety of pathophysiological conditions.

\section{References}

Alzheimer's Association Calcium Hypothesis Workgroup (2017) Calcium hypothesis of Alzheimer's disease and brain aging: a framework for integrating new evidence into a comprehensive theory of pathogenesis. Alzheimers Dement 13:178-182.e17.

Baver SB, Hope K, Guyot S, Bjørbaek C, Kaczorowski C, O’Connell KM (2014) Leptin modulates the intrinsic excitability of AgRP/NPY neurons in the arcuate nucleus of the hypothalamus. J Neurosci 34:5486-5496.

Berman DE, Dall'Armi C, Voronov SV, McIntire LB, Zhang H, Moore AZ, Staniszewski A, Arancio O, Kim TW, Di Paolo G (2008) Oligomeric amyloid- $\beta$ peptide disrupts phosphatidylinositol-4,5-bisphosphate metabolism. Nat Neurosci 11:547-554.

Cowley MA, Smith RG, Diano S, Tschöp M, Pronchuk N, Grove KL, Strasburger CJ, Bidlingmaier M, Esterman M, Heiman ML, Garcia-Segura LM, Nillni EA, Mendez P, Low MJ, Sotonyi P, Friedman JM, Liu H, Pinto S, Colmers WF, Cone RD, et al. (2003) The distribution and mechanism of action of ghrelin in the CNS demonstrates a novel hypothalamic circuit regulating energy homeostasis. Neuron 37:649-661.

Emmerzaal TL, Kiliaan AJ, Gustafson DR (2015) 2003-2013: a decade of body mass index, Alzheimer's disease, and dementia. J Alzheimers Dis 43:739-755.

Frere S, Slutsky I (2018) Alzheimer's disease: from firing instability to homeostasis network collapse. Neuron 97:32-58.

Fu H, Li W, Lao Y, Luo J, Lee NT, Kan KK, Tsang HW, Tsim KW, Pang Y, Li Z, Chang DC, Li M, Han Y (2006) Bis(7)-tacrine attenuates beta amyloid-induced neuronal apoptosis by regulating L-type calcium channels. J Neurochem 98:1400-1410.

Gao L, Blair LA, Salinas GD, Needleman LA, Marshall J (2006) Insulin-like growth factor-1 modulation of CaV1.3 calcium channels depends on $\mathrm{Ca}^{2+}$ release from IP3-sensitive stores and calcium/calmodulin kinase II phosphorylation of the alphal subunit EF hand. J Neurosci 26:62596268.

Gao S, Nguyen JT, Hendrie HC, Unverzagt FW, Hake A, Smith-Gamble V, Hall K (2011) Accelerated weight loss and incident dementia in an elderly African-American cohort. J Am Geriatr Soc 59:18-25.

Goodison WV, Frisardi V, Kehoe PG (2012) Calcium channel blockers and Alzheimer's disease: potential relevance in treatment strategies of metabolic syndrome. J Alzheimers Dis 30 [Suppl 2]:S269-S282.

Hsiao K, Chapman P, Nilsen S, Eckman C, Harigaya Y, Younkin S, Yang F, Cole G (1996) Correlative memory deficits, Abeta elevation, and amyloid plaques in transgenic mice. Science 274:99-102.

Ingwersen J, De Santi L, Wingerath B, Graf J, Koop B, Schneider R, Hecker C, Schröter F, Bayer M, Engelke AD, Dietrich M, Albrecht P, Hartung HP, Annunziata P, Aktas O, Prozorovski T (2018) Nimodipine confers clinical improvement in two models of experimental autoimmune encephalomyelitis. J Neurochem 146:86-98.

Ishii M, Iadecola C (2015) Metabolic and non-cognitive manifestations of Alzheimer's disease: the hypothalamus as both culprit and target of pathology. Cell Metab 22:761-776.

Ishii M, Wang G, Racchumi G, Dyke JP, Iadecola C (2014) Transgenic mice overexpressing amyloid precursor protein exhibit early metabolic deficits and a pathologically low leptin state associated with hypothalamic dysfunction in arcuate neuropeptide Y neurons. J Neurosci 34:9096-9106.

Johnson DK, Wilkins CH, Morris JC (2006) Accelerated weight loss may precede diagnosis in Alzheimer disease. Arch Neurol 63:1312-1317.

Kabir ZD, Lee AS, Rajadhyaksha AM (2016) L-type Ca(2+) channels in mood, cognition and addiction: integrating human and rodent studies with a focus on behavioural endophenotypes. J Physiol 594:5823-5837.

Kastanenka KV, Bussiere T, Shakerdge N, Qian F, Weinreb PH, Rhodes K, Bacskai BJ (2016) Immunotherapy with aducanumab restores calcium homeostasis in Tg2576 mice. J Neurosci 36:12549-12558.

Kim S, Rhim H (2011) Effects of amyloid- $\beta$ peptides on voltage-gated L-type $\mathrm{Ca}(\mathrm{V}) 1.2$ and $\mathrm{Ca}(\mathrm{V}) 1.3 \mathrm{Ca}(2+)$ channels. Mol Cells 32:289-294. 
Kohno D, Gao HZ, Muroya S, Kikuyama S, Yada T (2003) Ghrelin directly interacts with neuropeptide-Y-containing neurons in the rat arcuate nucleus: $\mathrm{Ca}^{2+}$ signaling via protein kinase $\mathrm{A}$ and $\mathrm{N}$-type channel-dependent mechanisms and cross-talk with leptin and orexin. Diabetes 52:948-956.

Koizumi K, Hattori Y, Ahn SJ, Buendia I, Ciacciarelli A, Uekawa K, Wang G, Hiller A, Zhao L, Voss HU, Paul SM, Schaffer C, Park L, Iadecola C (2018) Apoe4 disrupts neurovascular regulation and undermines white matter integrity and cognitive function. Nat Commun 9:3816.

Koschak A, Reimer D, Huber I, Grabner M, Glossmann H, Engel J, Striessnig J (2001) Alpha 1D (Cav1.3) subunits can form l-type $\mathrm{Ca}^{2+}$ channels activating at negative voltages. J Biol Chem 276:22100-22106.

Loh K, Herzog H, Shi YC (2015) Regulation of energy homeostasis by the NPY system. Trends Endocrinol Metab 26:125-135.

Lopez JR, Lyckman A, Oddo S, Laferla FM, Querfurth HW, Shtifman A (2008) Increased intraneuronal resting $\left[\mathrm{Ca}^{2+}\right]$ in adult Alzheimer's disease mice. J Neurochem 105:262-271.

Mattson MP (2007) Calcium and neurodegeneration. Aging Cell 6:337350.

McGuire MJ, Ishii M (2016) Leptin dysfunction and Alzheimer's disease: evidence from cellular, animal, and human studies. Cell Mol Neurobiol 36:203-217.

McKhann G, Drachman D, Folstein M, Katzman R, Price D, Stadlan EM (1984) Clinical diagnosis of Alzheimer's disease: report of the NINCDSADRDA work Group under the auspices of department of health and human services task force on Alzheimer's disease. Neurology 34:939-944.

Moreno CM, Dixon RE, Tajada S, Yuan C, Opitz-Araya X, Binder MD, Santana LF (2016) $\mathrm{Ca}(2+)$ entry into neurons is facilitated by cooperative gating of clustered CaV1.3 channels. Elife 5:e15744.

Pinggera A, Striessnig J (2016) Cav 1.3 (CACNA1D) L-type $\mathrm{Ca}^{2+}$ channel dysfunction in CNS disorders. J Physiol 594:5839-5849.

Scragg JL, Fearon IM, Boyle JP, Ball SG, Varadi G, Peers C (2005) Alzheimer's amyloid peptides mediate hypoxic up-regulation of L-type $\mathrm{Ca}^{2+}$ channels. FASEB J 19:150-152.

Treasure J, Zipfel S, Micali N, Wade T, Stice E, Claudino A, Schmidt U, Frank GK, Bulik CM, Wentz E (2015) Anorexia nervosa. Nat Rev Dis Primers 1:15074.

Ueda K, Shinohara S, Yagami T, Asakura K, Kawasaki K (1997) Amyloid $\beta$ protein potentiates $\mathrm{Ca}^{2+}$ influx through L-type voltage-sensitive $\mathrm{Ca}^{2+}$ channels: a possible involvement of free radicals. J Neurochem 68:265-271.
Ueno N, Dube MG, Inui A, Kalra PS, Kalra SP (2004) Leptin modulates orexigenic effects of ghrelin and attenuates adiponectin and insulin levels and selectively the dark-phase feeding as revealed by central leptin gene therapy. Endocrinology 145:4176-4184.

van den Pol AN, Yao Y, Fu LY, Foo K, Huang H, Coppari R, Lowell BB, Broberger C (2009) Neuromedin B and gastrin-releasing peptide excite arcuate nucleus neuropeptide $\mathrm{Y}$ neurons in a novel transgenic mouse expressing strong Renilla green fluorescent protein in NPY neurons. J Neurosci 29:4622-4639.

Wang JH, Wang F, Yang MJ, Yu DF, Wu WN, Liu J, Ma LQ, Cai F, Chen JG (2008) Leptin regulated calcium channels of neuropeptide $Y$ and proopiomelanocortin neurons by activation of different signal pathways. Neuroscience 156:89-98.

Wang L, Saint-Pierre DH, Taché Y (2002) Peripheral ghrelin selectively increases Fos expression in neuropeptide Y-synthesizing neurons in mouse hypothalamic arcuate nucleus. Neurosci Lett 325:47-51.

Weiss JH, Pike CJ, Cotman CW (1994) $\mathrm{Ca}^{2+}$ channel blockers attenuate $\beta$-amyloid peptide toxicity to cortical neurons in culture. J Neurochem 62:372-375.

White H, Pieper C, Schmader K (1998) The association of weight change in Alzheimer's disease with severity of disease and mortality: a longitudinal analysis. J Am Geriatr Soc 46:1223-1227.

Wu Q, Boyle MP, Palmiter RD (2009) Loss of GABAergic signaling by AgRP neurons to the parabrachial nucleus leads to starvation. Cell 137: $1225-1234$.

Xu W, Lipscombe D (2001) Neuronal Ca(V)1.3alpha(1) L-type channels activate at relatively hyperpolarized membrane potentials and are incompletely inhibited by dihydropyridines. J Neurosci 21:5944-5951.

Yanagi S, Sato T, Kangawa K, Nakazato M (2018) The homeostatic force of ghrelin. Cell Metab 27:786-804.

Zamponi GW (2016) Targeting voltage-gated calcium channels in neurological and psychiatric diseases. Nat Rev Drug Discov 15:19-34.

Zamponi GW, Striessnig J, Koschak A, Dolphin AC (2015) The physiology, pathology, and pharmacology of voltage-gated calcium channels and their future therapeutic potential. Pharmacol Rev 67:821-870.

Zott B, Simon MM, Hong W, Unger F, Chen-Engerer HJ, Frosch MP, Sakmann B, Walsh DM, Konnerth A (2019) A vicious cycle of $\beta$ amyloiddependent neuronal hyperactivation. Science 365:559-565. 